\title{
Abundance and vertical distribution of drifting, post-larval Macoma spp. (Bivalvia: Tellinidae) in the York River, Virginia, USA
}

\author{
Lance P. Garrison ${ }^{1,2, *}$, Jessica A. Morgan ${ }^{2}$ \\ ${ }^{1}$ Northeast Fisheries Science Center, National Marine Fisheries Service, 166 Water Street, \\ Woods Hole, Massachusetts 02543, USA \\ ${ }^{2}$ School of Marine Science, Virginia Institute of Marine Science, College of William and Mary, \\ Gloucester Point, Virginia 23062, USA
}

\begin{abstract}
We sampled the early drifting post-larvae of a complex of 2 species of tellinid bivalves, Macoma spp., at a station in the lower York River, Chesapeake Bay, USA. Plankton samples were collected by pump every $3 \mathrm{~h}$ from 3 depths (surface, mid-depth, and bottom) on 4 dates corresponding to full and new moons. Macoma spp. post-larvae (size range 400 to $500 \mu \mathrm{m}$ ) were abundant in the plankton throughout the sampling period. The environmental factors influencing the abundance and vertical distribution of drifting post-larvae were evaluated using linear and logistic regression. Post-larvae were always more abundant during night as compared to day and were more abundant during nocturnal, flooding tides than during ebbing tides. In general, they were closer to the surface at right and during flood tides, though these patterns were highly variable. These data indicate that drifting post-larval bivalves use 'selective tidal stream transport' to promote upstream dispersal as observed in the postlarvae of other estuarine taxa (e.g. crabs and fish). The post-larval stage generally re-invades juvenile habitats following the export of larvae to the mouth of the parent estuary or nearshore continental shelf. We suggest that small drifting post-larval bivalves exert behavioral control over suspension in the water column. This life-history stage serves to maintain high densities of juveniles and adults in the upstream portions of the York River estuary despite downstream transport of early larval stages.
\end{abstract}

KEY WORDS: Post-larval bivalves · Thread drifting · Tidal stream transport $\cdot$ Macoma spp.

\section{INTRODUCTION}

In estuarine systems, the input of freshwater results in net downstream transport of suspended materials. This physical characteristic imposes a life-history challenge upon estuarine invertebrates employing planktonic larvae. Taxa with high adult densities in the upper estuary require a mechanism for either retention of planktonic larvae near spawning sites or upstream transport of larvae against prevailing currents (Boehlert \& Mundy 1988). Larval swimming speeds in most invertebrate taxa are $<10 \mathrm{~mm} \mathrm{~s}^{-1}$ (Young 1995). While this does not allow active swimming against horizontal currents, larvae are generally capable of active

\footnotetext{
•E-mail: Igarriso@whsun1.wh.whoi.edu
}

vertical migration in the presence of weak vertical currents (Mann 1986, Boehlert \& Mundy 1988, Young 1995). Vertical migration at tidal periods within partially to well-mixed estuaries will result in directed horizontal transport due to the vertical stratification of velocity (Hill 1995). Behavioral control of suspension in the water column at tidal periods also allows directed transport. Larvae or post-larvae in a variety of taxa employ selective tidal stream transport and promote upstream dispersal by limiting their presence in the water column to periods of flooding tidal currents (Boehlert \& Mundy 1988).

The primary dispersal stage in most bivalves is the veliger. Bivalve veligers typically have swimming speeds ranging from 0.17 to $2.00 \mathrm{~mm} \mathrm{~s}^{-1}$ (Mann 1986 , Wang \& Xu 1997), are able to actively regulate depth, and perhaps undergo tidal-scale vertical migrations 
(Mann 1986). The extent to which veligers regulate transport through vertical migration in estuarine systems is unclear, and dispersal strategies are highly variable. In general, the degree of behavioral depth regulation is higher in estuarine and shallow water species than in oceanic species (Mann 1986). A general pattern of ontogenetic shifts in vertical distribution is also apparent in species across different estuaries. Older larvae are generally more abundant near the bottom than younger larvae, presumably due to increases in specific gravity and changes in velum morphology (Mann 1986, Jacobsen et al. 1990. Mann et al. 1991, Baker 1993, Wang \& Xu 1997). Higher abundance near the bottom enhances upstream transport in later life-history stages due to residual upstream movement of high salinity bottom waters (Pritchard 1952, Jacobsen et al. 1990). This general pattern suggests net downstream transport of early veligers near the surface with eventual sinking and slow upstream transport of older larvae by residual, non-tidal currents.

Bivalve larvae metamorphose into a juvenile form following a planktonic period ranging from 1 to $5 \mathrm{wk}$ (Lutz et al. 1991). Juveniles range in size from $300 \mu \mathrm{m}$ to several $\mathrm{mm}$ in length (Chanley \& Andrews 1971). Traditionally, post-metamorphic bivalves were considered to be sessile after initial settlement; however, it is increasingly apparent that extensive dispersal can be accomplished during the early juvenile or post-larval period (Armonies 1994, 1996, Baker \& Mann 1997. Wang \& Xu 1997). The period of post-larval dispersal is frequently longer than the larval period, suggesting that transport during this life-history stage may be extremely important to population dynamics (Baker \& Mann 1997, Wang \& Xu 1997).

In bivalve post-larvae, locomotion is typically accomplished by drifting on long, trailing byssal or mucous threads (Sigurdson et al. 1976, Lane et al. 1985, Baker 1993). Threads increase drag and provide lift, enabling post-larvae to leave the substrate and float (Sigurdson et al. 1976, Lane et al. 1985. Cummings et al. 1993). Drifting post-larval bivalves extend the thread to rise in the water column and retract the thread to sink (Sigurdson et al. 1976, de Blok \& Tan-Maas 1977), potentially allowing active depth regulation. Both vertical position and resuspension are strongly dependent on current velocity. Bivalve post-larvae actively produce drifting threads and change their orientation in the sediments to promote resuspension and transport; however, physical processes in the water column determine the degree of resuspension and dispersal (Baker \& Mann 1997)

Drifting Macoma spp. post-larvae are abundant in the York River, a sub-estuary of southern Chesapeake Bay (Baker \& Mann 1997). Post-larvae in this system typically range from 400 to $500 \mu \mathrm{m}$ and are very recently metamorphosed juveniles. The post-larval stage plays an important role in the population dynamics of a variety of estuarine taxa including crustaceans (Olmi 1993) and larval fish (Boehlert \& Mundy 1988). In general, this life-history stage utilizes selective tidal stream transport or vertical migration behaviors to promote upstream transport and re-invasion of the adult habitat following initial downstream transport during the larval period. A complex of 2 species of the genus Macoma (Bivalvia: Tellinidae) occur in the upriver, mesohaline reaches of estuaries in the Chesapeake Bay system (Baker \& Mann 1997). The majority of the Macoma spp. in the York River are Macoma balthica; however, Macoma mitchelli may occur in significant numbers (Seitz 1996, R. Mann pers. comm.). The maintenance of populations in upriver regions requires a mechanism for recruitment despite net downstream transport of planktonic larvae. We hypothesize that the drifting post-larval stage accomplishes directed upstream transport and provides a mechanism for reinvasion of juvenile and adult habitats. We contrast the role of the post-larval stage in the York River, an estuarine system, with that observed in the Wadden Sea, a coastal oceanic system.

\section{MATERIALS AND METHODS}

Study site. Post-larval bivalves were collected from the Virginia Institute of Marine Science ferry pier in the lower York River, Chesapeake Bay, USA, during summer 1995 (Fig. 1). The York River is a partially mixed estuary, with a tidal period of approximately $12.4 \mathrm{~h}$. The mean depth of the water column was $3 \mathrm{~m}$, with a tidal range of approximately $1.0 \mathrm{~m}$. Samples were collected on 4 dates coinciding with the full (13 June and 12 July 1995) and new (27 June and 27 July 1995) moons.

Sample collection and environmental data. Three centrifugal water pumps were used to sample post-larvae from 3 depths: $0.5 \mathrm{~m}$ below the surface (Surface), $0.5 \mathrm{~m}$ above the bottom (Bottom), and $1 / 2$ the distance between these depths (Mid-Depth). Intakes were positioned so as to prevent disruption of flow by pier pilings and other structures. Outflow was filtered through a 202 um mesh plankton net.

Samples were taken every $3 \mathrm{~h}$ over $24 \mathrm{~h}$, beginning at 00:00 h Eastern Daylight Time on each date. For each sample depth, 3 to 4 replicates were collected during each period. Samples consisted of 5 min pumping periods (sample volume $=2.25$ to $2.73 \mathrm{~m}^{3}$ ). Replicates were randomized over position on the pier $(20$ locations at $1 \mathrm{~m}$ intervals), pump ( 3 pumps), and order of collection to prevent statistical bias. 
Fig. 1 Study site. Map of the York River and Chesapeake Bay showing the location of the sampling site (Virginia Institute of Marine Science ferry pier)

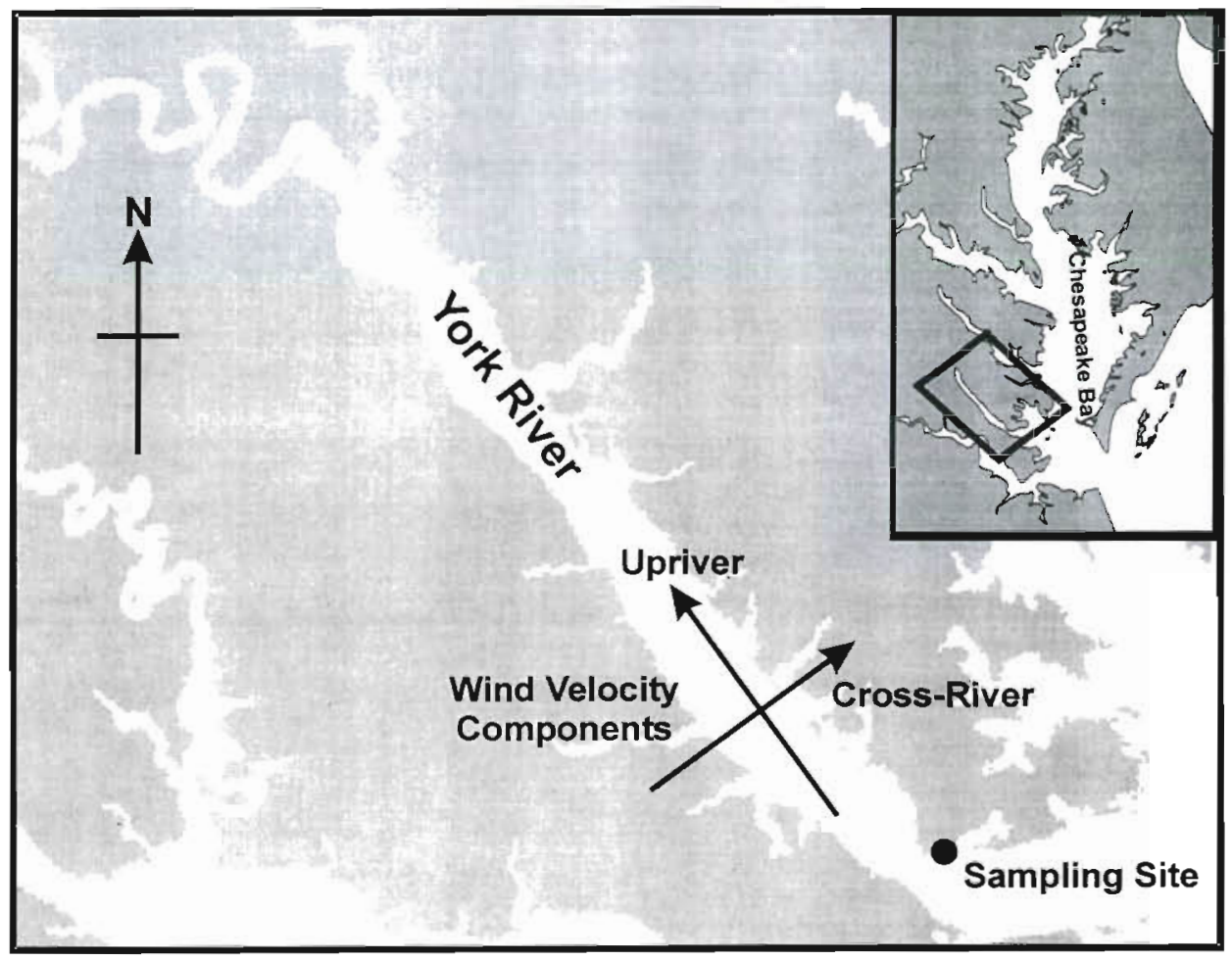

Captured plankton were fixed in $5 \%$ formalin and transferred to $70 \%$ EtOH for sorting. Sub-samples were split to $1 / 2$ to $1 / 16$ with a Folsom splitter, and counts were made of post-larval bivalves.

Data on water column and atmospheric characteristics were obtained from the Virginia Institute of Marine Science Data Collection Center (VIMS 1995). Salinity and temperature were measured at $6 \mathrm{~min}$ intervals from a mid-depth probe suspended from the VIMS ferry pier. Salinity records were not available on 27 July 1995 due to equipment failure. Wind speed $\left(\mathrm{m} \mathrm{s}^{-1}\right)$ and direction (degrees from North) were obtained from an anemometer at the Virginia Institute of Marine Science. Measured wind speed and direction were converted into upriver and cross-river velocity components. The upriver component reflected the wind velocity directed along the primary axis of the York River (wind direction $\cong 135^{\circ}$ from North). The crossriver component was orthogonal to the upriver component and was positive going from the eastern to western shores of the river in the main portion of the river (Fig. 1). Tide height in meters above mean lower low water (MLLW) was measured at a NOAA tide gauge station approximately $50 \mathrm{~m}$ from the study site.

Species identification. The bivalves collected from the zooplankton were identified as post-metamorphic (i.e. post-larval) based upon a number of morphological characteristics. First, the size of all specimens ranged between 400 and $500 \mu \mathrm{m}$, which is well beyond the size range typically achieved by larvae (Chanley $\&$ Andrews 1971). Bivalve veligers are typically $<300 \mu \mathrm{m}$ in length. Baker \& Mann (1997) also observed that Macoma spp. collected at this site $>330 \mu \mathrm{m}$ in length were generally post-metamorphic. Second, the specimens observed lacked a velum and had a broadly triangular foot. Mucous threads were rarely observed. Handling procedures during sample collection and storage likely resulted in the retraction of drifting threads, limiting the usefulness of this indicator. Finally, the presence of the prodissoconch II/dissoconch boundary was clearly observed in the shell morphology, confirming that we were examining early post-metamorphic juveniles.

For species identification, post-larval bivalves were treated in a $5.25 \%$ solution of sodium hypochlorite for approximately $5 \mathrm{~min}$ to digest away soft tissues and ligaments (Fuller \& Lutz 1989). The disarticulated valves were rinsed in distilled water and observed under dissecting and compound microscopes for identification. Shell length (anterior to posterior) was measured using an ocular micrometer and computer image analysis following video capture of the microscope image. Gross morphology, shell length, hinge structure, and number of hinge teeth were used to classify the specimens according to identification keys (Sullivan 1948, Webb 1986, Kennedy et al. 1989).

Random sampling of collected post-larvae was conducted to compare morphological measurements (i.e. 
prodissoconch II length, length:width ratios, etc.) and confirm species identifications. The umbo was angular (Chanley \& Andrews 1971), and there was no visible eyespot (pigmented spot). A single large tooth was observed in the posterior region of the hinge of all sampled post-larvae. While all examined specimens were identified as Macoma balthica based upon direct comparison with microphotographs in Sullivan (1948), it is probable that some proportion of the sampled postlarvae were from $M$. mitchelli, which is also present in the York River (Baker \& Mann 1997). Only a small proportion $(<1 \%)$ of the collected post-larvae were directly examined. Given the difficulty in directly examining hinge structure and thereby positively identifying all specimens to the species level, we have chosen to be conservative in our analysis and refer to patterns in the 2-species complex, Macoma spp.

Statistical analyses: post-larval concentration. The influence of physical and atmospheric forcing on postlarval concentration was examined using a multiple linear regression model (see Table 1). Raw data were log-transformed $\left\{\right.$ In [(post-larvae $\left.\left.\left.\mathrm{m}^{-3}\right)+1\right]\right\}$ to satisfy the assumptions of the analysis (Underwood 1981, Zar 1984). Light stage (day vs night), tidal current stage (ebb vs flood), and depth were included as categorical 'dummy' variables (Zar 1984). In addition, the regression model included the influence of salinity, temperature, tide height, and upriver and crossriver wind components (see Table 1). Hourly means of these factors during each sampling period were used. Because both salinity and temperature were significantly correlated with date and there were large differences in mean post-larval concentration across dates, separate regression models were examined for each day to avoid confounding effects. Explanatory variables were selected using a stepwise procedure and residuals were examined to ensure model validity.

Statistical analyses: vertical distribution. A logistic regression model was used to explicitly test the influence of explanatory variables on the depth distribution of post-larvae (Agresti 1989, Hosmer \& Lemeshow 1989). The response variable was depth. The polytomous model using all 3 depths did not meet the proportional odds assumption $(p<0.001)$, therefore response levels were collapsed into a binomial response (Hosmer \& Lemeshow 1989). The model evaluated the probability of post-larvae being in the surface sample versus the combined mid-depth and bottom samples. There was no qualitative difference between this model and the alternative model testing differences between the combined surface and mid-depth samples versus bottom samples.

Explanatory variables were date, current, and light. Overall model significance was assessed by the $-2 \log$ likelihood estimation chi-squared, while model fit was assessed with the likelihood ratio goodness-of-fit test (Agresti 1989). Influence plots of residuals were examined to verify model fit (Hosmer \& Lemeshow 1989).

The preliminary model with date (D), current (C), and light (L) as main effects did not meet the goodnessof-fit test. Therefore, potential 2- and 3-way interaction effects were examined and included as appropriate to build the best model following Hosmer \& Lemeshow (1989). Additionally, the response was non-linear over the 4-level date effect, so this variable was collapsed into a binary explanatory variable $(1=$ Dates 13 and 27 June; 2 = Dates 12 and 27 July) (Hosmer \& Lemeshow 1989). This grouping of adjacent dates resulted in a linear response and provided the best model fit compared to other groupings. The model including the binary date response, the 2 -way $\mathrm{D} \times \mathrm{C}$ interaction, and the 3 way $\mathrm{D} \times \mathrm{C} \times \mathrm{L}$ effects best fit the data.

\section{RESULTS}

\section{Post-larval concentration}

The patterns in post-larval concentration were remarkably consistent across the 4 sampling dates. The highest concentrations were observed during nocturnal flooding tides and high tides $(21: 00$ and $00: 00 \mathrm{~h}$, Fig. $2 \mathrm{~A}$ to $\mathrm{D}$ ). In general, post-larval concentrations were nearly an order of magnitude higher during these periods as compared to other times. Post-larval concentration declined but remained high during nocturnal ebbing tides and near low tide $100: 00$ and 03:00 h, Fig. $2 \mathrm{~A}$ to $\mathrm{D})$. Concentrations were generally extremely low during daylight hours (06:00 to $18: 00 \mathrm{~h})$ on all 4 dates. However, a consistent tidal signal was also apparent during the day. Post-larval concentrations were generally higher during daytime flooding tides (06:00 and 09:00 h) as compared to daytime ebbing and low tides (12:00 and 15:00 h). Drifting Macoma spp. post-larvae were most abundant in the water column during nocturnal flooding tides, were less abundant during nocturnal ebb tides, and were relatively rare during daylight hours.

The water column (e.g. temperature and salinity) and atmospheric (e.g. wind velocity) signals were highly variable between dates. The mean water temperature increased across sampling dates from approximately $23^{\circ} \mathrm{C}$ on $13 \mathrm{June}$ to approximately $30^{\circ} \mathrm{C}$ on 27 July (Fig. 3), and mean salinity decreased across dates from approximately 20.3 psu on 13 June to 18.5 psu on 12 July (Fig. 3). These parameters are weakly related to tidal signals in this region of the York River. However, temperature generally rose during ebbing tides (e.g. 27 June, 12 July, and 27 July; Fig. 3) while salinity 
generally increased during flooding tides (e.g. 13 June and 12 July; Fig. 3). The relationship between wind components and the salinity and temperature signals was highly variable (Fig. 3).

The multiple regression models reflected the variation in the physical environment between dates. The regression models were all significant and explained $>60 \%$ of the variation in post-larval concentration. Postlarval concentrations were consistently higher at night (Table 1). The lack of a significant light effect on 12 July is likely due to confounding between the temperature and salinity signals and the light signal (i.e. temperature was higher at night and salinity was lower at night; Fig. 3E). The significant current stage effects (e.g. 13 and 27 June) indicated higher concentrations during flooding tides (Table 1). Where significant relationships between post-larval concentration and water column parameters occurred, they were consistent with high post-larval concentrations during periods of upstream transport. Post-larval concentration was negatively correlated with temperature (13 June), positively correlated with salinity (27 June), positively correlated with upriver wind velocity $(12$ July), and positively correlated with tide height (27 July; Table 1).

\section{Vertical distribution}

The vertical distribution of post-larvae was best modeled by a logistic regression including date, current, light, and their interaction effects. The overall model was highly significant and the non-significant maximum likelihood goodness-of-fit test indicated that the model explained a significant amount of the variation in the data (Table 2; Agresti 1989).

Date was a highly significant predictor of vertical position and had a negative parameter

Fig. 2. Post-larval concentration and tidal height Post-larval concentrations by depth and tidal height for each sampling time on each day. Error bars reflect SE of mean concentration. No samples were taken at 00:00 h on 13 June (A). Tide height was measured by tide gauge in meters above MLLW at 6 min intervals. Night (black) and day (white) are noted on the light phase bar at the top of the figure. Sunrise was at approximately $05: 30 \mathrm{~h}$ and sunset was at approximately 20:30 h on all days. Please note scale differences between plots
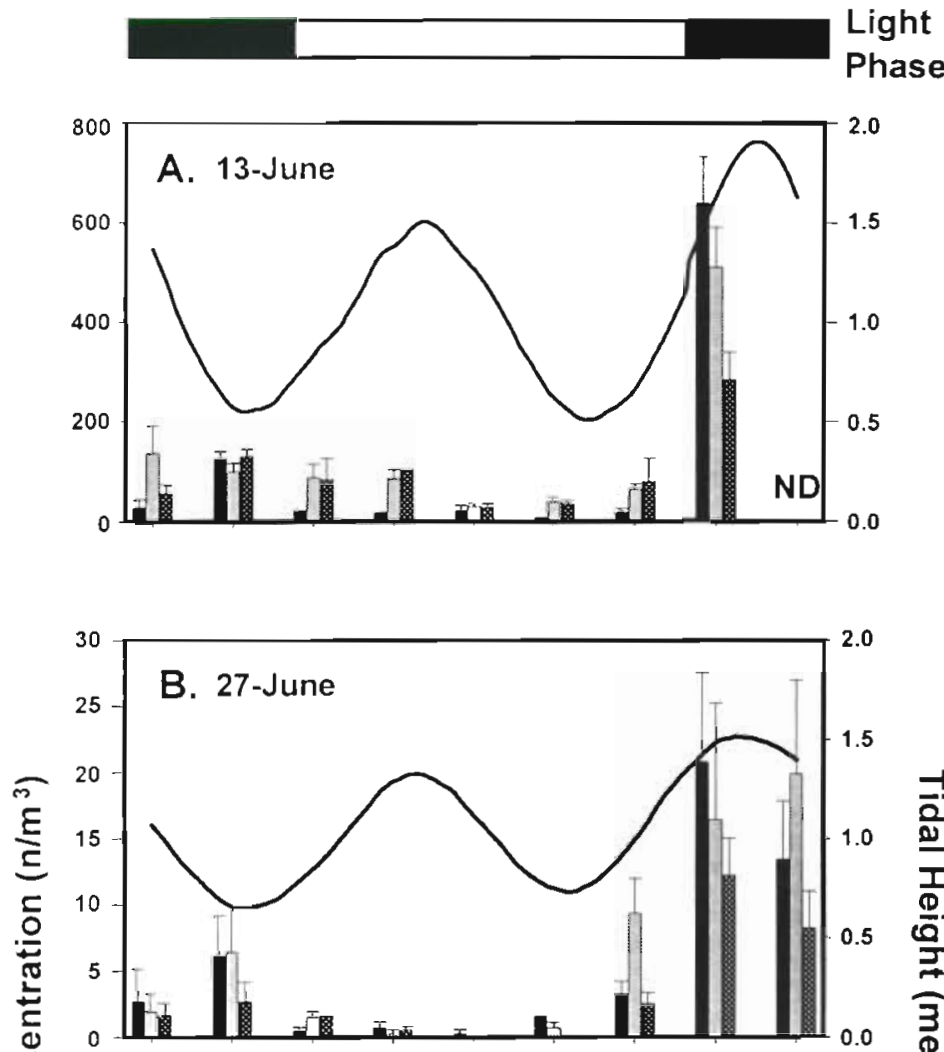

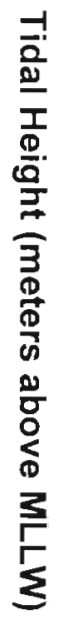

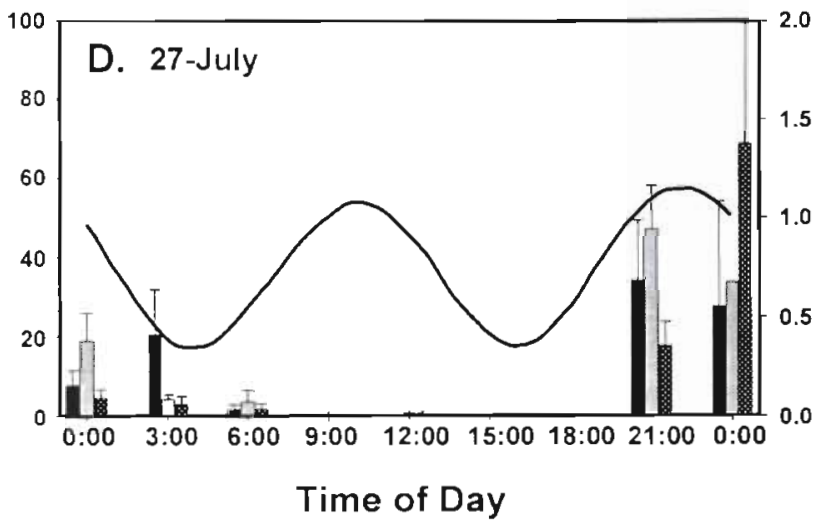

Surface $\quad$ Mid-Depth 䋞 Bottom 
A. 13-June

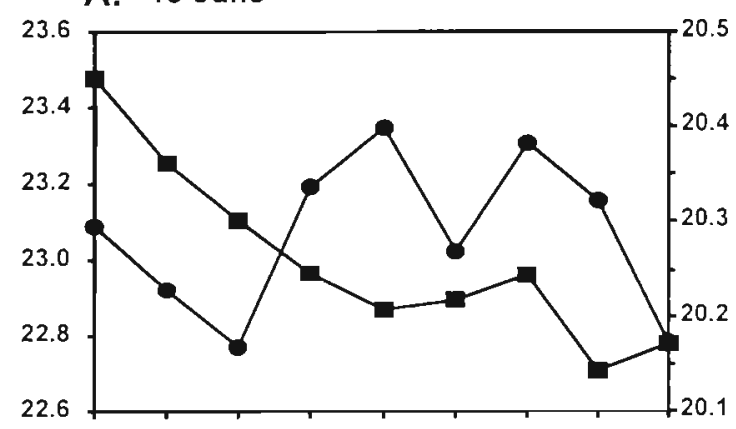

C. 27-June
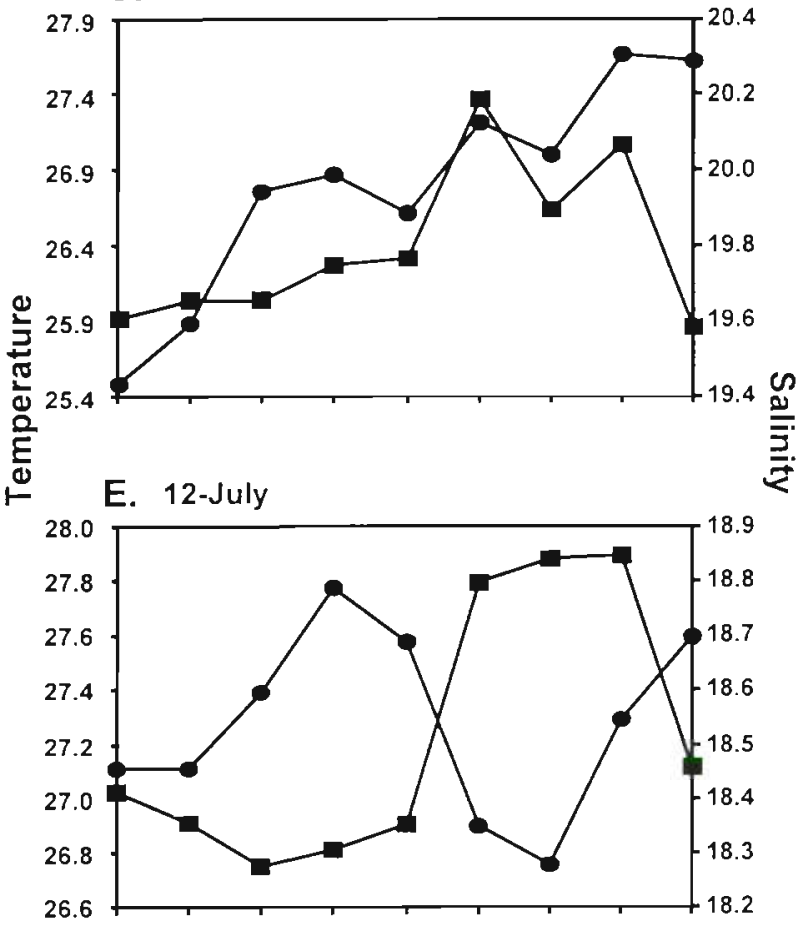

G. 27-July

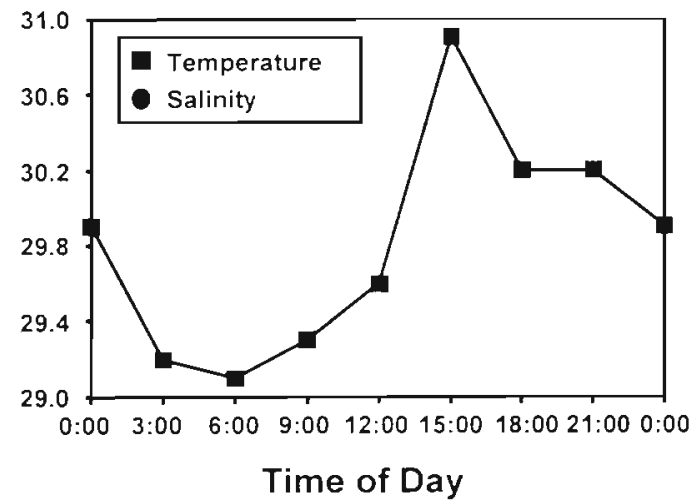

B. 13-June

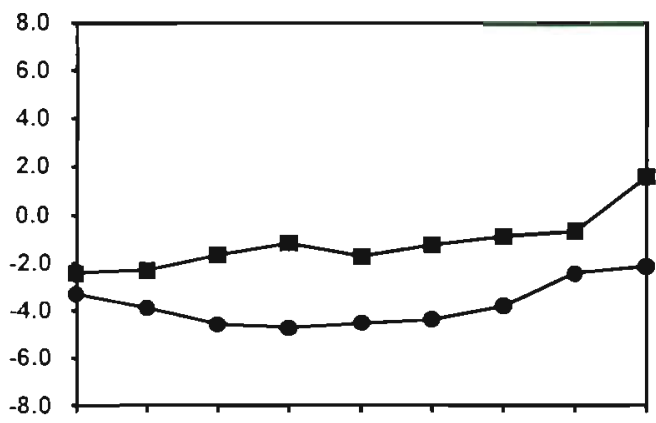

D. 27-June

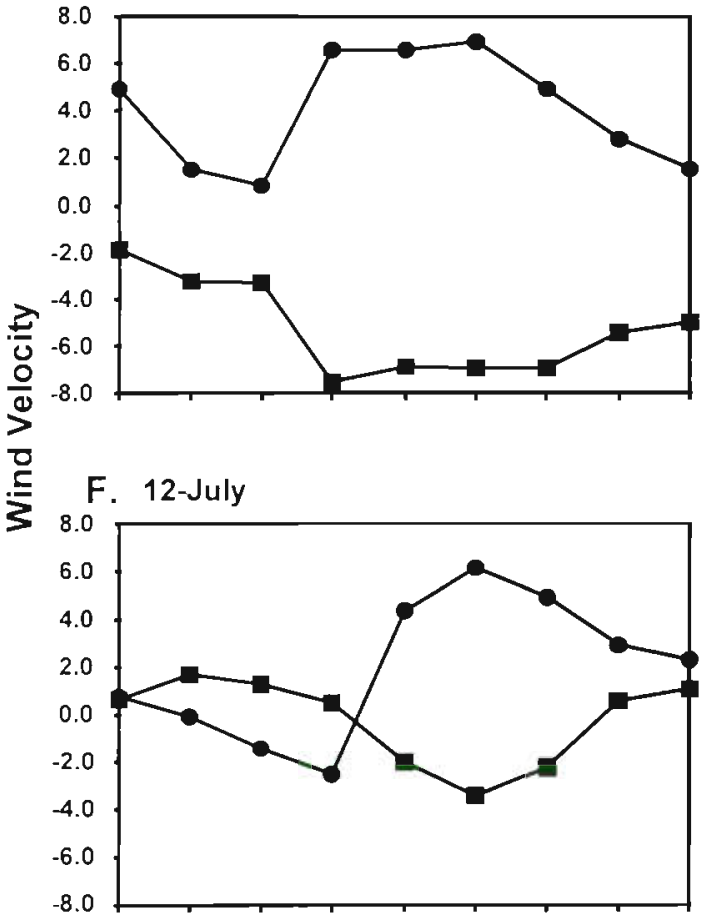

H. 27-July

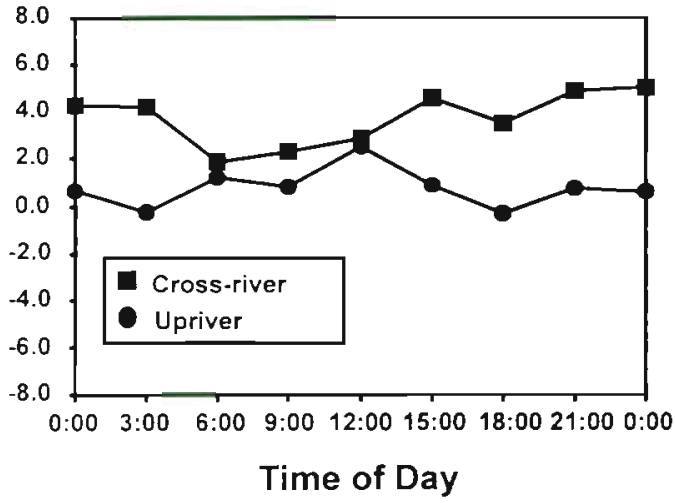

Fig. 3. Water column parameters and wind velocity. Hourly means of physical parameters including temperature, salinity, and wind velocity components by date. Temperature and salinity values are hourly means of 6 min measurements at mid-depth for each sampling interval. No salinity data was available on $27 \mathrm{July}(\mathrm{G})$. Wind velocity (speed and direction) was converted into upriver and cross-river orthogonal components as depicted in Fig. 1. Hourly averages of 6 min measurements are shown for each 
Table 1. Multiple regression of environmental characteristics on log-transformed post-larval concentration. Separate multiple regression models were generated for each date to avoid confounding by mean temperature and salinity differences between dates. Regressors were selected by a stepwise method. Explanatory variables included: temperature (T), salinity (S), upriver wind velocity (UW), cross-river wind velocity $(\mathrm{CW})$, light (L: $0=$ night, $1=$ day), current stage $(\mathrm{CS}: 0=$ flood, $1=$ ebb), tide height $(\mathrm{TH})$; and 2 dummy variables reflecting depth level $(Z 1=$ mid-depth, $Z 2=$ bottom) relative to surface. Regression parameters $(\beta)$ for variables retained in each model are shown. NA indicates missing salinity data on 27 July. Significance of $\beta$ as indicated by $t$-test: $\cdots p<0.001, \cdots p<0.01, " p<0.05, \mathrm{NS}_{0.05} \leq \mathrm{p}$

\begin{tabular}{|lcccccccccccc}
\hline Date & T & S & UW & CW & L & CS & TH & Z1 & Z2 & Model $x^{2}$ Model F & df \\
\hline 13 June & $-1.59 \cdots$ & - & - & - & $-1.95 \cdots$ & $-0.89 \cdots$ & - & $0.98 \cdots$ & $0.84 \cdots$ & 0.695 & $27.74 \cdots$ & 5,61 \\
27 June & - & $1.98 \cdots$ & - & - & $-1.75 \cdots$ & $-0.68 \cdots$ & $-0.81^{\text {NS }}$ & - & - & 0.669 & $30.37 \cdots$ & 5,75 \\
12 July & - & $0.87^{\text {Nh }}$ & $0.41 \cdots$ & $0.837 \cdots$ & - & - & - & - & - & 0.601 & $51.66 \cdots$ & 3,103 \\
27 July & - & NA & - & - & $-2.01 \cdots$ & - & $1.11 \cdots$ & $0.33^{\text {NS }}$ & - & 0.610 & $47.91 \cdots$ & 3,92 \\
\hline
\end{tabular}

value (Table 2), indicating that post-larvae were lower in the water column during the July samples (Fig. 4A, B). The significant current effect indicated that larvae were more likely to be near the surface during flood tides, and the light effect indicated that larvae were nearer the surface at night (Table 2, Fig, 4A,B).

Both the $\mathrm{C} \times \mathrm{L}$ and $\mathrm{D} \times \mathrm{C} \times \mathrm{L}$ interaction effects were significant, reflecting variability in the responses modeled in the main effects (Table 2 ). This is primarily driven by the daytime samples on the first 2 dates. Postlarvae were closer to the surface during ebb tides at this time, in contrast to the patterns of the other date, current, and light combinations (Fig. 4A).

\section{DISCUSSION}

Post-larval Macoma spp. were consistently more abundant during the night, indicating light-driven behavioral control of drifting in the York River. In addition, larval concentration was significantly higher during flooding currents as opposed to ebbing currents and was positively correlated with upstream transport of water (e.g. upriver wind, low temperature, high

Table 2. Logistic regression results. Three explanatory variables (date, current, and light) were included in the model. The 2-way and 3-way interaction effects were included to improve model fit to the data. The overall model was significant with -2 log likelihood estimated chi-squared $=355.291$ and $p<0.001$ The model fit to the observed data was excellent with a likelihood ratio chi-squared $=0.72$ and $p=0.698$.

$$
\cdots p<0.001, \cdots p<0.01
$$

\begin{tabular}{|lrrrrr|}
\hline Variable & df & Parameter & SE & Odds ratio & Chi-squared \\
\hline Intercept & 1 & 1.696 & 0.088 & & $371.889 \cdots$ \\
Date (D) & 1 & -0.339 & 0.066 & 0.712 & $26.496 \cdots$ \\
Current (C) & 1 & -0.611 & 0.060 & 0.543 & $103.393 \cdots$ \\
Light (L) & 1 & -1.199 & 0.073 & 0.302 & $270.964 \cdots$ \\
C $\times$ L & 1 & 2.368 & 0.565 & 10.870 & $17.805 \cdots$ \\
D $\times$ C $\times$ L & 1 & -1.453 & 0.533 & 0.234 & $7.437 \cdots$ \\
\hline
\end{tabular}

salinity, and higher tide heights). In general, the relationship between post-larval concentration and water column and atmospheric parameters was weak and

\section{A. Dates 13-June and 27-June}

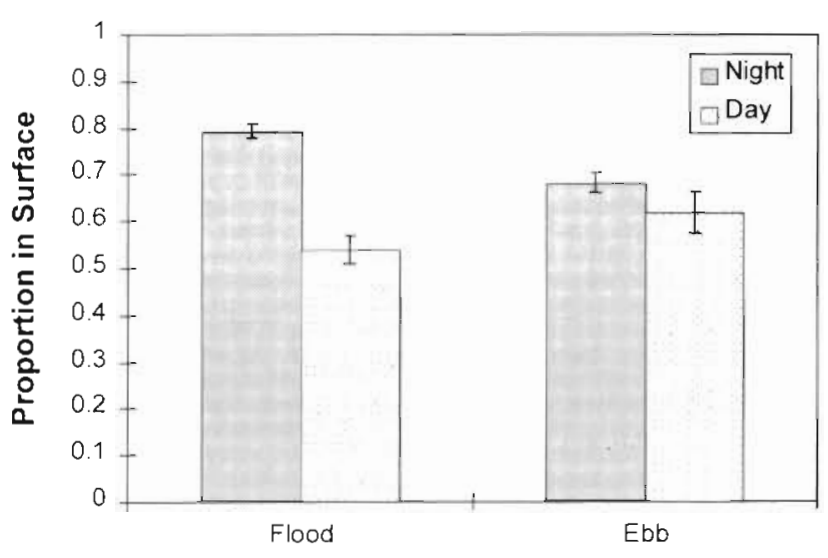

B. Dates 13-July and 27-July

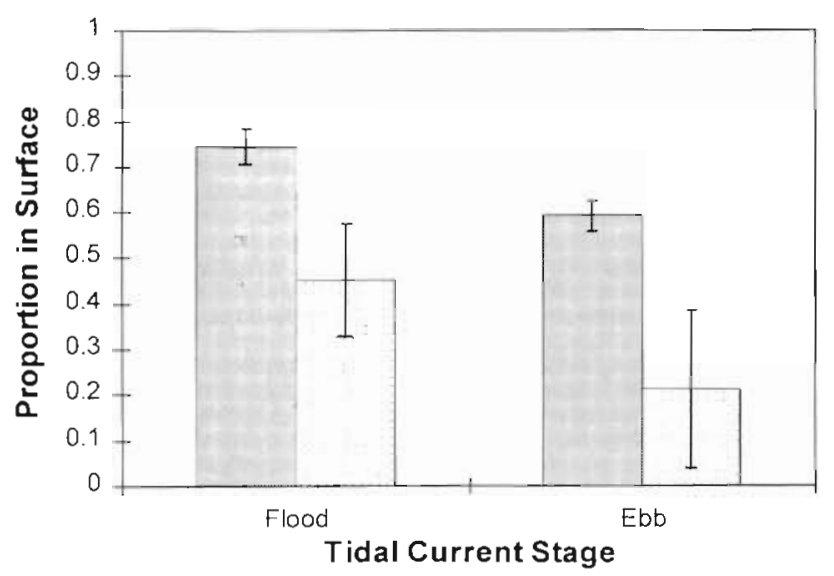

Fig. 4. Logistic regression results. Observed proportions of post-larvae in surface samples for (A) June and (B) July. Error bars represent $95 \% \mathrm{CI}$ 
variable while the relationship with light and tidal current stage was strong and consistent. We conclude from these data that post-larval Macoma spp. exert behavioral control over their abundance in the water column and employ nocturnal, flood-phased selective tidal stream transport to promote movement upstream.

Macoma balthica and $M$. mitchelli adults are primarily distributed in the mesohaline (salinity $\cong 5$ to $10 \mathrm{psu}$ ) regions of the York River 10 to $20 \mathrm{~km}$ upriver from the study site (Dauer et al. 1987, Seitz 1996, Mann unpubl. data), and they are relatively rare in downriver, highsalinity regions of the Chesapeake Bay (Mansour 1992. Mann unpubl. data). It is therefore unlikely that the post-larvae we collected originated from large spawning aggregations downstream of our sampling site. The post-larvae observed in this study are likely recruits returning to upstream adult populations following initial downstream dispersal during the veliger stage.

The vertical migration behavior and subsequent transport of Macoma spp. veligers have not been studied in this system, and the vertical migration and transport of bivalve larvae in general remain poorly understood (Mann 1988). A variety of laboratory studies have indicated that veligers are capable of active depth regulation and respond to environmental stimuli such as temperature, salinity, and pressure (Mann 1986, 1988, Mann et al. 1991, Wang \& Xu 1997). Upward swimming speeds in young veligers are generally higher than sinking speeds, suggesting that they may maintain position near the surface in early stages. The maintenance of position. near the surface will result in net downstream transport associated with non-tidal downstream flow in the York River estuary (Garrison 1997).

In later veliger stages, bivalve larvae are generally more abundant near the bottom (Jonsson et al. 1991, Mann et al. 1991, Wang \& Xu 1997). The abundance of late pediveligers of Macoma spp. and other bivalves was always highest near the bottom at a study site near ours (Baker 1993). Older larvae may be concentrated near the bottom either due to physical forcing such as frontal boundaries with high vertical velocities (e.g. Mann 1988) or due to behavioral and physiological changes in later veliger stages (Mann et al. 1991, Wang \& Xu 1997). Passive physical processes such as the subduction of higher salinity water from the Chesapeake Bay upon entering a tributary may also maintain high concentrations of bivalve veligers in bottom waters and promote retention or upstream transport independent of larval behavior (Boicourt 1982). If latestage veligers maintain position near the bottom in partially to well-mixed estuarine systems, their net transport will be upstream due to net residual upstream transport of high-salinity water input at the estuary mouth (Pritchard 1952)
In the absence of tidally driven vertical migration behaviors, both early and late stage veligers depend upon residual currents for net horizontal transport. The rate of residual transport in both surface and bottom waters is dependent upon the rate of freshwater input at the head of the estuary and the mixing associated with wind and vertical density gradients (Pritchard 1952). Residual currents in estuarine systems are typically an order of magnitude lower than tidal currents. Therefore, decoupling larval or post-larval transport from the residual current field will result in both faster and more predictable directed transport (Queiroga et al. 1997). This process underlies the selective tidal stream transport observed in diverse taxa in estuarine systems (Boehlert \& Mundy 1988, Queiroga et al. 1997). By maintaining position near or attached to the bottom during ebbing tides and rising into the water column during flooding tides, planktonic larvae can achieve very high rates of net directed upstream transport. Maximum tidal current speeds near the surface in the York River estuary are typically on the order of $1 \mathrm{~m}$ $\mathrm{s}^{-1}$, resulting in a potential dispersal range on the order of $10 \mathrm{~km}$ per tidal cycle. Tidal current velocity typically declines with depth due to frictional effects, therefore larvae maintaining position closer to the surface will experience the maximum rate of net transport (Hill 1995, Queiroga et al. 1997).

The profile of abundance and vertical distribution observed in post-larvae of other taxa utilizing selective tidal stream transport mirrors the patterns observed in the post-larval Macoma spp. in the present study. Both early juvenile fish (Boehlert \& Mundy 1988) and postlarval crabs (Olmi 1993) are abundant in surface waters during nocturnal flood tides, and they are absent from the water column or near the bottom during ebbing tides and daylight. Night time dispersal is typically seen as an adaptation to reduce predation on larvae in the plankton (Boehlert \& Mundy 1988). The downstream transport of early planktonic larval forms with subsequent re-invasion of upstream adult and juvenile habitats appears to be a general life-history characteristic in estuarine taxa (Baker \& Mann 1997). Macoma spp. appears to employ a similar mechanism to maintain adult populations in the mesohaline regions of the York River. Small veligers are transported downstream and likely sink in later stages, resulting in slow upstream dispersal as late veligers. Shortly after metamorphosis, our data indicate that rapid upstream dispersal is accomplished by thread drifting post-larvae that exert a behavioral control over transport during nocturnal flooding tides.

Unlike other estuarine taxa, settled post-larval bivalves do not have a mechanism for active swimming in the water column. Therefore, the rate of transport and vertical position in the water column will be 
dependent upon the strength of tidal or wind-driven currents. This is especially true in shallow habitats (like the one sampled in the current study) that are susceptible to strong vertical mixing and high near-bottom water velocity associated with wind events. The abundance of post-larval Macoma balthica in the Wadden Sea was highly dependent on both current velocity and wind speed (Beukema \& de Vlas 1989, Armonies 1992, 1996). The more limited control of transport in Macoma spp. post-larvae in our study is apparent from their presence in the water column during nocturnal ebbing tides and the high variability in vertical position (Fig. 2). In contrast, the post-larvae of the blue crab Callinectes sapidus are completely absent from the water column during ebb tides because they are capable of actively swimming and attaching to the bottom or submerged aquatic vegetation (Olmi 1993). The production of threads by bivalve post-larvae is behaviorally controlled; however, the degree and rate of transport depend strongly upon the velocity of tidal and wind-driven currents.

Despite this dependence upon physical mechanisms, the post-larvae observed in the present study exhibited remarkable behavioral control over abundance in the water column. The 4 sampling dates all had different temperature, salinity, and wind patterns reflecting different physical and flow regimes over the course of the study. The observed variation in depth distribution and mean abundance likely reflect the influence of this physical variability. The variation in the relationship between post-larval concentration and water column parameters indicates that post-larvae were not responding strongly to particular environmental cues or flow characteristics. However, the patterns of post-larval abundance were highly consistent between dates despite this variation, indicating the importance of behavioral control of post-larval transport. De Wolf (1974, 1981) and Boicourt (1982) argued that tidal stage differences in larval or post-larval abundance may be associated with asymmetry in the tidal current speed between stages. Tidal currents in the York River

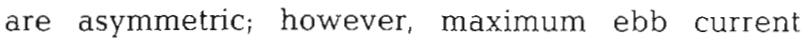
velocities are typically twice as large as flood currents. If post-larval transport was strongly dependent upon current speed, it would be expected that post-larval concentration would be highest during ebbing tides or highly correlated with wind speed. These patterns were not observed in the current study, and post-larval concentration was typically highest during nocturnal flooding tides independent of other physical signals.

Drifting post-larvae also play an important role in the life-history and population dynamics of Macoma balthica in the Wadden Sea system. Studies in the Wadden Sea (e.g. Beukema \& de Vlas 1989. Armonies 1992, 1996. Beukema 1993) focused on the role of larger $(0.7$ to $10 \mathrm{~mm}$ length) post-larvae in the redistribution of juvenile populations reflecting ontogenetic changes in habitat preference. Drifting post-larval $M$. balthica were more abundant at night than day in the Wadden Sea during the summer months (Armonies 1996). The abundance of larger post-larval $M$. balthica during winter months was strongly correlated with tidal current speed, and they were more abundant during ebbing tides, resulting in net offshore transport in the Wadden Sea population (Beukema \& de Vlas 1989). $M$. balthica post-larvae in the Wadden Sea also showed periodic variation in drifting behavior on a $10 \mathrm{~d}$ cycle (Armonies 1992). The migrations observed in the Wadden Sea reflect different habitat preferences for successive size classes (Beukema 1993). The summer shoreward migration of small individuals likely compensated for local spat loss and provided a potential refuge from predation in the upper tidal zone (Armonies 1992, 1996). The offshore winter migration of large individuals may reflect a movement to warmer, deep waters promoting higher growth rates and reproductive output during the adult phase (Beukema 1993, Armonies 1996).

The processes controlling post-larval distribution in the Wadden Sea system are similar to those observed in the present study; however, the role of post-larvae in Macoma spp. population dynamics reflects different selective factors unique to each ecosystem. The most noticeable difference between post-larvae in the Wadden Sea system and those in the present study is the size difference. No post-larvae $>500 \mu \mathrm{m}$ in length were captured in the current study, while those in the Wadden Sea ranged up to $10 \mathrm{~mm}$ in size. This is likely a function of the location of the sampling site in the current study. There are very low densities of large (e.g. 5 to $10 \mathrm{~mm}$ ) juvenile Macoma spp. in regions near the mouth of the York River. High juvenile abundances occur in tidal creeks several kilometers upstream of the study site and further upstream near adult populations (Seitz 1996). Therefore, the post-larvae we sampled reflect recently settled recruits being transported into the York River estuary from the Chesapeake Bay. There is some indication of seasonal redistribution of larger juveniles in the York River reflecting ontogenetic shifts in habitat preference similar to the Wadden Sea system (Lipcius \& Seitz unpubl. data). Sampling in the upstream portions of the York River may indicate the redistribution of juveniles in size ranges similar to those in the Wadden Sea

The transport of large post-larvae in the Wadden Sea is highly dependent upon physical forcing. Post-larval abundance was highly correlated with the maximum current speed (Beukema \& de Vlas 1989) and strongly correlated with wind velocity (Armonies 1992). In contrast, the transport of post-larvae in the York River 
estuary was less associated with physical forcing and more strongly associated with behavioral patterns. This is likely due to differences in post-larval size between the studies. Larger post-larvae will require much higher current speeds for resuspension than small post-larvae. Typical tidal currents are sufficient to promote resuspension in the York River system, decoupling post-larval transport trom stochastic physical forcing

The upstream portions of estuaries are generally more productive than downstream habitats, allowing higher growth potential for juvenile and adult populations. In addition, there is generally higher predation pressure in the plankton in upstream habitats and shallow tidal creeks due to high concentrations of larval fish (Morgan 1995). These selective pressures are thought to promote the downstream dispersal of decapod crab zoeae as a refuge from predation with subsequent re-invasion of upstream habitats in the post-larval stage (Morgan 1990, 1995). Similar patterns of larval export with post-larval or juvenile return occur in larval fish (Boehlert \& Mundy 1988), barnacles (de Wolf 1974, 1981), and polychaetes (Thiébaut et al. 1996). This may reflect a common response to selective pressures in estuarine systems among diverse invertebrate taxa. In this study, we have documented similar behavioral patterns in small, drifting post-larval bivalves. The net downstream transport in estuarine systems necessitates a mechanism for the return of weakly swimming larvae to adult populations. Recently metamorphosed drifting post-larvae appear to fill this vital role in York River populations of Macoma spp

Acknowledgements. The authors gratefully acknowledge the assistance provided by R. Mann and J. Harding during the identification of post-larvae and K. Garrison in the collection of plankton samples. R. Mann, S. L. Sanderson, H. Ducklow, and 3 anonymous reviewers provided insightful reviews of the manuscript. Funding for equipment and supplies was provided by the NOAA Office of Sea Grant, US Department of Commerce, Grant No. NA-90AA-D-SG-45, to the Virginia Marine Science Consortium and Virginia Sea Grant College Program. Financial support for J.A.M. was provided by the NSF-REU program at the Virginia Institute of Marine Science. Support for L.P.G. was generously provided by a doctoral fellowship from the W. A. Van Engel Foundation. Virginia Institute of Marine Science Contribution No. 2229

\section{LITERATURE CITED}

Agresti A (1989) Categorical data analysis. John Wiley and Sons, Inc, New York

Armonies W (1992) Migratory rhythms of drifting juvenile molluscs in tidal waters of the Wadden Sea. Mar Ecol Prog Ser 83:197-206

Armonies W (1994) Turnover of postlarval bivalves in sediments of tidal flats in Königshafen (German Wadden Sea) Helgal Meeresunters 48:291-297
Armonies W (1996) Changes in distribution patterns of 0 group bivalves in the Wadden Sea: byssus-drifting releases juveniles from the constraints of hydrography. J Sea Res 35(4):323-334

Baker PK (1993) Quantification of settlement and recruitment processes in bivalve mollusks. PhD dissertation, College of William and Mary, Williamsburg, VA

Baker PK, Mann R (1997) The post-larval phase of bivalve mollusks: a review of functional ecology and new records of post-larval drifting in Chesapeake Bay bivalves. Bull. Mar Sci 61:409-430

Beukema JJ (1993) Successive changes in distribution patterns as an adaptive strategy in the bivalve Macoma balthica (L.) in the Wadden Sea. Helgol Meeresunters 47 $287-304$

Beukema JJ, de Vlas J (1989) Tidal current transport of thread-drifting postlarval juveniles of the bivalve Macoma balthica from the Wadden Sea to the North Sea. Mar Ecol Prog Ser 52:193-200

Boehlert GW, Mundy BC (1988) Roles of behavioral and physical factors in larval and juvenile fish recruitment to estuarine nursery areas. Am Fish Soc Symp 3:51-67

Boicourt WC (1982) Estuarine larval retention mechanisms on 2 scales. In: Kennedy VS (ed) Estuarine comparisons. Academic Press, New York, p 445-457

Chanley P, Andrews JD (1971) Aids for identification of bivalve larvae of Virginia. Malacologia 11:45-119

Cummings VJ, Pridmore RD, Thrush SF, Hewitt JE (1993) Emergence and floating behaviours of post-settlement juveniles of Macoma litiana (Bivalvia: Tellinacea). Mar Behav Physiol 24:25-32

Dauer DM. Ewing RM, Rodi AJ (1987) Macrobenthic distribution within the sediment along an estuarine salinity gradient: benthic studies of the lower Chesapeake Bay 8. Int Rev Gesamten Hydrobiol 72(5):529-538

de Blok JW, Tan-Maas M (1977) Function of byssus threads in young postlarval Mytilus. Nature 267:558

de Wolf $\mathrm{P}$ (1974) On the retention of marine larvae in estuaries. Thalassia Jugosl 10:415-424

de Wolf $P(1981)$ Is retention a result of active or passive phenomena? Estuaries 4:239

Fuller SC, Lutz RA (1989) Shell morphology of larval and post-larval mytilids from the north-western Atlantic. J Mar Biol Assoc UK 69:181-218

Garrison LP (1997) The influence of physical transport and nutritional stress on the zoeae of estuarine crabs. $\mathrm{PhD}$ dissertation, The College of William and Mary, Williamsburg, VA

Hill AE (1995) The kinematic principles governing horizontal transport induced by vertical migration in tidal flows. J Mar Biol Assoc UK 75:3-13

Hosmer DW, Lemeshow S (1989) Applied logistic regression. John Wiley and Sons, Inc, New York

Jacobsen TR, Milutinovic JD, Miller JR (1990) Observational and model studies of physical processes affecting benthic larval recruitment in Delaware Bay. J Geophys Res 93(C2): $1329-1334$

Jonsson PR. Andre C, Lindegarth M (1991) Swimming behavior of marine bivalve larvae in a flume boundary-layer flow: evidence for near-bottom confinement. Mar Ecol Prog Ser 79:67-76

Kennedy VS, Lutz RA, Fuller SC (1989) Larval and early postlarval development of Macoma mitchelli Dall (Bivalvia: Tellinidae). Veliger 32:29-38

Lane DJW, Beaumont AR. Hunter JR (1985) Byssus drifting and the drifting threads of the young post-larval mussel Mytilus edulis. Mar Biol 84:301-308 
Lutz RA, Chalermwat K. Figueras AJ, Gustafson RG, Newell $C$ (1991) Mussel aquaculture in marine and estuarine environments throughout the world. In: Menzel W (ed) Estuarine and marine bivalve mollusk culture. CRC Press, Boca Raton, p 57-95

Mann R (1986) Sampling of bivalve larvae. In: Jamieson GS, Bourne $N$ (eds) North Pacific workshop on stock assessment and management of invertebrates. Can Spec Publ Fish Aquat Sci 92:107-116

Mann R (1988) Distribution of bivalve larvae at a frontal system in the James River, Virginia. Mar Ecol Prog Ser 50:29-44

Mann R, Campos BM, Luckenbach MW (1991) Swimming rate and responses of larvae of three mactrid bivalves to salinity discontinuities. Mar Ecol Prog Ser 68:257-269

Mansour RA (1992) Foraging ecology of the blue crab, Callinectes sapidus Rathbun, in lower Chesapeake Bay. PhD dissertation, The College of William and Mary, Williamsburg, VA

Morgan SG (1990) lmpact of planktivorous fishes on dispersal, hatching, and morphology of estuarine crab larvae. Ecology 71(5): 1639-1652

Morgan SG (1995) Life and death in the plankton: larval mortality and adaptation In: McEdward L (ed) Ecology of marine invertebrate larvae. CRC Press, Boca Raton, p 279-322

Olmi EJ (1993) Immigration of blue crab (Callinectes sapidus) megalopae in the York River, Virginia: patterns and processes. PhD dissertation, The College of William and Mary, Williamsburg, VA

Pritchard DW (1952) Salinity distribution and circulation in the Chesapeake Bay estaurine system. J Mar Res 11:106-123

Queiroga $H$, Costlow JD, Moreira MH (1997) Vertical migration of the crab Carcinus maenas first zoea in an estuary: implications for tidal stream transport. Mar Ecol Prog Ser 149:121-132

Editorial responsibility: Joseph Pawlik (Contributing Editor), Wilmington, North Carolina, USA
Seitz RD (1996) The role of epibenthic predators in structuring marine soft-bottom communities along an estuarine gradient. PhD dissertation. The College of William and Mary, Williamsburg, VA

Sigurdson JB, Titman CW, Davies PA (1976) The dispersal of young post-larval bivalve molluscs by byssus threads Nature 262:386-387

Sullivan CM (1948) Bivalve larvae of Malpeque Bay, PEI [Prince Edward Island]. Fish Res Board Can Bull 77 : $1-36$

Thiébaut E, Dauvin JC, Wang Z (1996) Tidal transport of Pectinaria koreni postlarvae (Annelida: Polychaeta) in the Bay of Seine (eastern English Channel). Mar Ecol Prog Ser 138:63-70

Underwood AJ (1981) Techniques of analysis of variance in experimental marine biology and ecology. Oceanogr Mar Biol Annu Rev 19:513-605

VIMS (1995) York River ambient monitoring data, June-July 1995. VIMS Scientific Data Archive (http://www. vims.edu/data_archive). Virginia Institute of Marine Science, Gloucester Pt, VA

Wang WX, Xu ZZ (1997) Larval swimming and postlarval drifting behavior in the infaunal bivalve Sinonovacula constricta. Mar Ecol Prog Ser 148:71-81

Webb CM (1986) Post-larval development of the tellinacean bivalves Abra alba, Tellina fabula, and Dondx vittatus (Mollusca: Bivalvia) with reference to the late larva. J Mar Biol Assoc UK 66:749-762

Young CM (1995) Behavior and locomotion during the dispersal phase of larval life. In: McEdward LR (ed) Ecology of marine invertebrate larvae. CRC Press, Boca Raton, p $249-278$

Zar JH (1984) Biostatistical analysis. Prentice Hall, Englewood Cliffs, NJ

Submitted: March 9, 1998; Accepted: December 28, 1998 Proofs received from author(s): May 31, 1999 